\title{
Home range and activity of African goshawks Accipiter tachiro in relation to their predation on bats
}

\section{I.L. RAUTENBACH , M.B. FENTON, A.C. KEMP and S.J. VAN JAARSVELD.}

\author{
Rautenbach, I.L., M.B. Fenton, A.C. Kemp and S.J. van Jaarsveld. 1990. Home range \\ and activity of African goshawks Accipiter tachiro in relation to their predation on \\ bats. Koedoe 33(2): 17-21. Pretoria. ISSN 0075-6458.
}

\begin{abstract}
Winter radio-tracking of three African goshawks Accipiter tachiro showed that they each occupied well-wooded home ranges of at least 28 hectares. They perched and roosted mainly within densely foliaged trees and an adult female changed perches on average 4,7 times per hour. No crepuscular predation of bats was recorded, in contrast to regular summer predation on colonies of little free-tailed bats, Tadarida pumila, but winter emergence rates of these bats at dusk had dropped to $\leq 5 \%$ of the previous summer. We predict that many accipiters will be regular predators of bats and that skewed sex ratios and high fecundity may be two means by which bats counter this predation.
\end{abstract}

Key words: Accipiter tachiro, home range, activity, bats, predation.

I.L. Rautenbach and A.C. Kemp, Transvaal Museum, P.O. Box 413, Pretoria, 0001 Republic of South Africa; M.B. Fenton, Department of Biology, York University, 4700 Keele Street, Ontario, Canada M3J IP3; S.J. van Jaarsveld, African Raptor Information Centre, P.O. Box 59507, Karenpark, Pretoria, 0118 Republic of South Africa.

\section{Introduction}

In the summer of 1987-88, a pair of African goshawks Accipiter tachiro (Daudin, 1800) were observed to prey regularly on little freetailed bats, Tadarida pumila (Cretzschmar, 1830-1831), at a bridge in the Kruger National Park (Kemp \& Rautenbach 1987; Van Jaarsveld 1988). The present study attempts to document the home range, activity and foraging behaviour of African goshawks in the same area during the winter of 1988 .

\section{Materials and Methods}

Three goshawks were caught and fitted with radio transmitters attached to their tail feathers. A subadult male (NM) with almost complete adult plumage was trapped on 15 June at the lowwater bridge over the Sabie River, $2 \mathrm{~km}$ NE of Skukuza $\left(24^{\circ} 59^{\prime} 30^{\prime \prime} \mathrm{S}\right.$; $\left.31^{\circ} 36^{\prime} 0^{\prime \prime} \mathrm{E}\right)$. The adult female (BF) of a pair at the highwater bridge over the Sabie River, $13 \mathrm{~km} \mathrm{E}$ of Skukuza ( $24^{\circ} 57^{\prime} 30^{\prime \prime} \mathrm{S}$; $\left.31^{\circ} 43^{\prime} 0^{\prime \prime} \mathrm{E}\right)$ was caught on 17 June and the adult male (SM) of a pair resident in the staff village at Skukuza $\left(24^{\circ} 59^{\prime} 30^{\prime \prime} \mathrm{S} ; 31^{\circ} 35^{\prime} 0^{\prime \prime} \mathrm{E}\right)$ on 22 June.

Checks were made at least twice daily on the location of each bird from when it was trapped to the end of the study on 26 June using directional Yagi antennas and Yaesu FT-290R receivers. Individual birds were followed between 22-25 June, from 06:00 to 18:00 (sunrise 06:53, sunset 17:25).

\section{Results}

All three birds normally perched in evergreen trees with dense foliage and took flight if approached more closely than 40 metres. BF was visible when perched on $2 \%$ of occasions when observers were estimated to be within $50 \mathrm{~m}$, whereas SM was visible $7 \%$ of the time. Visual observations suggested that the birds were solitary for most of the time but we saw a male flying with BF at dawn on two days. On these occasions they were passing the locations at the bridge where they were observed preying on emerging bats during summer. Only a few bats emerged from the roost 


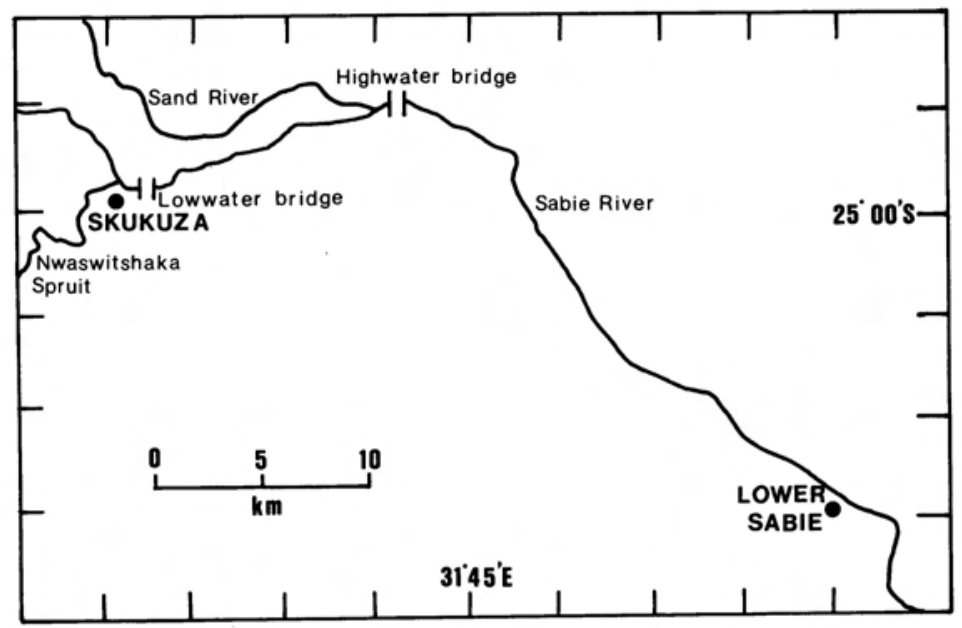

Fig. 1. A map of the Skukuza area, Kruger National Park, showing the locations at which Accipiter tachiro were trapped and the river systems along which they were radio-tracked.

during this study, and no attempts at predation were made by the goshawks.

NM remained at the lowwater bridge over the Sabie River for seven days (15-21 June, Fig. 1). It then moved $10 \mathrm{~km}$ downriver to the highwater bridge on 21 June where it spent part of that day and the night in the home range of BF. It remained at the highwater bridge until 08:00 on 22 June when it left the area and was never located again, despite an aerial search on 24 June along the Sabie and Sand rivers from $3 \mathrm{~km}$ west of Skukuza to 3 $\mathrm{km}$ west of Lower Sabie.

The SM was tracked on 22 June (Table 1) when it ranged about $500 \mathrm{~m}$ south of riparian forest along the Sabie River into a dry, densely-wooded strip along the Nwaswitshaka watercourse (Fig. 1). It perched in densely foliaged evergreen trees and roosted that night in such a tree about $200 \mathrm{~m}$ south of the river. It made an unsuccessful attempt to catch a laughing dove Streptopelia senegalensis (Linnaeus, 1766). Perch changes were not always associated with attacks on prey, because the goshawk also moved when mobbed by birds such as white helmetshrikes Prionops plumata (Shaw, 1809).

The bridge female BF was tracked on 22, 23, 24 and 25 June (Table 1) when it ranged from $800 \mathrm{~m}$ east to $600 \mathrm{~m}$ west of the bridge (Fig. $1)$, spending most of the day on either bank in this 28 ha strip of riparian forest. It spent three periods of 31,61 and 55 minutes, on 22,23 and 25 June respectively $(5,5 \%$ of the fourday, $44,9 \mathrm{~h}$ active periods) in dry woodland adjacent to the riparian forest. During the night it roosted in dense riparian vegetation, the first two nights about $100 \mathrm{~m}$ east of the bridge and the next two nights at different locations west of the bridge.

SM changed perches on average 1,7 times/ hour and BF 4,7 times/hour (range 0-17), much more frequently than the male. Both moved $50-100 \mathrm{~m}$, rarely up to $500 \mathrm{~m}$, at each perch change. $\mathrm{BF}$ changed perches most frequently between 06:00-08:00 on 22 June when NM was present, and she may have been interacting with this male. BF was also 
Table 1

The number of perch changes recorded for radio-tagged male and female African goshowks Accipiter tachiro during winter near Skukuza in the Kruger National Park

Individual, date and activity period

Perch changes per hour starting at:

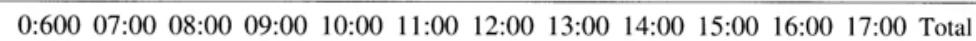

\begin{tabular}{llllllllllllll}
\hline SM, 22 June & 3 & 0 & 2 & 2 & 3 & 2 & 0 & 0 & 1 & 2 & 3 & 2 & 20 \\
$06: 00-17: 35(1 \mathrm{~h}$ 35min)
\end{tabular}

\begin{tabular}{|c|c|c|c|c|c|c|c|c|c|c|c|c|c|}
\hline \multicolumn{14}{|l|}{ BF, 22-24 June } \\
\hline $06: 05-17: 39$ (11h $34 \mathrm{~min})$ & 17 & 12 & 3 & 2 & 3 & 5 & 0 & 2 & 2 & 4 & 2 & 5 & 57 \\
\hline $06: 09-17: 26(11 \mathrm{~h} 17 \mathrm{~min})$ & 6 & 5 & 2 & 0 & 1 & 4 & 11 & 6 & 5 & 7 & 6 & 6 & 59 \\
\hline $06: 18-17: 33(11 \mathrm{~h} 15 \mathrm{~min})$ & 2 & 5 & 7 & 4 & 5 & 0 & 6 & 2 & 3 & 1 & 5 & 4 & 44 \\
\hline $06: 18-17: 05(10 \mathrm{~h} 47 \mathrm{~min})$ & 2 & 5 & 7 & 11 & 6 & 3 & 1 & 3 & 6 & 6 & 2 & 1 & 53 \\
\hline Total & 27 & 27 & 19 & 17 & 15 & 12 & 18 & 13 & 16 & 18 & 15 & 16 & 213 \\
\hline Average & $8,51^{1}$ & 6,8 & 4,8 & 4,3 & 3,8 & 3,0 & 4,5 & 3,3 & 4,0 & 4,5 & 3,8 & $9,3^{1}$ & 4,7 \\
\hline
\end{tabular}

${ }^{1}$ Averages only for that time when female was active

more active at 12:00-13:00 on 23 June and at 09:00-10:00 on 24 June when hunting in the dry woodland adjacent to the river.

\section{Discussion}

Our data suggest that in winter a male and female African goshawk occupied home ranges of about 28 ha each, centred on a riverine forest where they perched within densely foliaged trees. Adults appear to reside in such areas, based both on our observations during summer (Kemp \& Rautenbach 1987; Van Jaarsveld 1988) and on those of other observers (Steyn 1982; Piper 1989), but their total home range is probably larger, if we accept nesting records near Skukuza of adjacent nests being 3,3-3,7 km apart (Simmons 1990). The extensive movements of NM suggest a subadult searching for a permanent territory - behaviour rarely documented for raptors.
The goshawks became active before sunrise and continued after sunset, overlapping with the dusk emergence of bats, but no winter predation of bats was recorded. At dusk during previous summers a pair of goshawks preyed regularly on Tadarida pumila as they emerged from the highwater bridge (Kemp \& Rautenbach 1987; Van Jaarsveld 1988). During our study the number of bats emerging at dusk was $\leq 5 \%$ of that during summer (Rautenbach, Van der Merwe \& Vivier unpubl. data).

Although numbers and diversity seemingly make bats attractive prey for raptors, their small size and nocturnal habits may protect most bats from all but specialized raptors such as bat hawks Macheirhamphus alcinus Westerman, 1851. However, aggregation in colonies may number thousands to tens of thousands of individuals, making bats attractive to predators, even to those less specialized than bat hawks. Around large colonies, high prey density may translate into high encounter and capture rates that turn otherwise 
unprofitable prey into an important resource. There are many records of raptors harvesting bats departing from large colonies (Rupprecht 1979; Van der Merwe 1980; Hill \& Smith 1984), and in summer African goshawks took 1-5 Tadarida pumila per evening in our study area (Kemp \& Rautenbach 1987; Van Jaarsveld 1988). This translates into $12-60 \mathrm{~g}$ of food for birds averaging $362 \mathrm{~g}$ (Maclean $1985)$, or $22-111 \%$ of their estimated daily food requirements ( $15 \%$ of body mass). Concentrations of bats can therefore provide important feeding opportunities for goshawks and other similar predators (Allen 1939; Kunz 1974).

Colonial roosting clearly carries costs to the bats which may be countered by other benefits. At roosts in buildings at Skukuza T. pumi$l a$ and the Angola free-tailed bat T. condylura (A. Smith, 1833) raise up to three offspring per female per breeding season (Van der Merwe, Rautenbach \& Van der Colf 1986), perhaps a reflection of the favourable microclimate of the artificial roosts. Vivier (1989) found that $70 \%$ of 149 houses examined in the Skukuza staff village were occupied by colonies of $T$. pumila and T. condylura with average colony sizes of 205 and 348 individuals respectively, and a sex ratio in $T$. pumila of one male to 2,85 females. This productivity, which exceeds that of many other bats (Racey 1982), may be one of the direct benefits of colonial roosting. The $95 \%$ reduction of the emergence rate of Tadarida in winter when the bats are not bearing young supports this interpretation. Diminished colony size could, however, also reflect the seasonal distribution and availability of insect prey (Rautenbach, Kemp \& Scholtz 1988).

We predict that further research will reveal that many accipiters are important predators of colonial bats and that the bats may employ high fecundity and skewed sex ratios to compensate for such predation.

\section{Acknowledgements}

We thank the Warden of the Kruger National Park, Dr. S.C.J. Joubert, the Assistant Head: Research, Dr. V. de Vos, and the Control Research Officer, Dr. W.P.D. Gertenbach for permission to undertake this research in the Park, and are grateful to Dr. L.E.O. Braack for advice and Mr. I. de Beer for assistance. Mr. G. van Urk, Development Engineer of the Physics Department, Potchefstroom University for Christian Higher Education deserves a special word of appreciation for designing and building transmitters for this particular project. This undertaking was financed by Foundation for Research Development grants to ILR and $\mathrm{ACK}$, with vehicle support from the Peregrine Fund.

\section{References}

ALLEN, G.M. 1939. Bats. Cambridge: Harvard University Press.

HILL, J.E. and J.D. SMITH. 1984. Bats, A Natural History. London: British Museum (Natural History).

KEMP, A.C. and I.L. RAUTENBACH. 1987. Bat hawks or bat-eating hawks? Gabar 2(2):4-6.

KUNZ, T.H. 1974. Reproduction, growth, and mortality of the vespertilionid bat, Eptesicus fuscus, in Kansas. Journal of Mammalogy 55:1-13.

MACLEAN, G. L. 1985. Roberts' Birds of Southern Africa. Cape Town: John Voelcker Bird Book Fund.

PIPER, S. E. 1989. Interesting recapture of an African Goshawk. Gabar 4(2):23-24.

RACEY, P.A. 1982. Ecology of bat reproduction. Pp. 57-104. In: KUNZ, T.H. (ed.). Ecology of Bats. New York: Plenum Press.

RAUTENBACH, I.L., A.C. KEMP and C.H. SCHOLTZ. 1988. Fluctuations in availability of arthropods correlated with microchiropteran and avian predator activites. Koedoe 31: 77-90.

RUPPRECHT, A.L. 1979. Bats (Chiroptera) as constituents of the food of barn owls Tyto alba in Poland. Ibis 121: 489-494.

SIMMONS, R. 1990. African goshawk encounter. African Wildlife 44(2):91.

STEYN, P. 1982. Birds of Prey of Southern Africa. Cape Town: David Philip.

VAN JAARSVELD, J. 1988. African goshawks and European hobbies bat-hawking. Gabar 3: 29-31.

VAN DER MERWE, M. 1980. Importance of $\mathrm{Mi}$ niopterus schreibersii natalensis in the diet of barn owls. South African Journal of Wildlife Research 10: 15-17.

VAN DER MERWE, M., I.L. RAUTENBACH and W.J. VAN DER COLF. 1986. Reproduction in females of the little free-tailed bat Tadarida (Chaerephon) pumila (Cretzschmar, 1826) 
(Microchiroptera: Molossidae) in the eastern Transvaal, South Africa. Journal of Reproduction and Fertility 77: 355-364.

VIVIER, L. 1989. The reproduction, food preferences, sociobiology and ecology of Tadarida pumila and Tadarida condylura in the Kruger National Park, with special emphasis on commensalism and related problems. B.Sc. (Hons.) report, University of Pretoria, Pretoria. 